Karolina Drozdowska

Uniwersytet Gdański

\title{
Zmagania z mitem. Dorastanie i śmierć w literackiej relacji Linn Ullmann ${ }^{1}$
}

\author{
Coping with the myth - growing up and death in Linn Ullmann's novel Unquiet
}

\begin{abstract}
The aim of this text is to analyze Linn Ullmann's novel Unquiet (published in 2015) as a literary account of a family history and death of the author's father, Ingmar Bergman. The article concentrates on how Ullmann, through different formal strategies, manages to tell a very intimate story without reducing it to tabloid-like coverage. First, the article briefly discusses autobiographism, biographism, autofiction and performative biographism as dominating tendencies in Norwegian literature in the 2010's, placing Ullmann's novel in this context. Secondly, theoretical perspectives which might be employed in the process of analyzing Unquiet are defined. Lastly, the novel's form is analyzed with regard to this particular approach. The article's aim is to present Linn Ullmann's Unquiet as a novel hybrid in its form, and thus, an one-of-a-kind phenomenon in modern Norwegian literature.
\end{abstract}

Key words: Linn Ullmann, Ingmar Bergman, Unquiet, autofiction, Norwegian literature

Słowa klucze: Linn Ullmann, Ingmar Bergman, De urolige, autofikcja, literatura norweska

\section{Będziesz pisał własne życie}

W lutym 1889 roku w Kristianii ukazał się ósmy numer czasopisma Impresjonisten, uchodzącego za organ miejskiego awangardowego środowiska literackiego oraz artystycznego, określanego mianem „bohemy z Kristianii” (norw. Kristiania-bohemen). Ten konkretny numer Impresjonisten przeszedł do historii z uwagi na wydrukowane w nim słynne „dziewięcioro przykazań bohemy”. Pierwsze, a zatem można uznać, że najważniejsze przykazanie głosiło: „Będziesz pisał swoje własne życie”2 (Svanholm 2001: 105). I choć współcześni historycy norweskiej literatury

\footnotetext{
${ }^{1}$ Niniejszy tekst powstał w kwietniu 2018 r. przed ukazaniem się we wrześniu polskiego przekładu powieści (Ullmann 2018). Dlatego też wszystkie cytaty z książki w części analitycznej niniejszego tekstu przytaczane są w przekładzie autorki artykułu (przyp. red.).

${ }^{2}$ Oryg. „Du skal skrive dit eget liv”. Cytaty ze źródeł obcojęzycznych, jeśli nie podano inaczej, przytaczam we własnym tłumaczeniu, podając dodatkowo w przypisie ich oryginalne brzmienie.
} 
nie mają pewności co do tego, kto konkretnie te „przykazania” sformułował (wedle jednych teorii - „guru” ówczesnej bohemy Hans Jæger, wedle zaś innych - wydawcy Impresjonisten, tj. Johan Collett Michelsen oraz Christian Krohg i jego żona Oda) (Bjørnstad 2001: 550), nie sposób nie stwierdzić, iż osoba ta zapewne zupełnie niechcący („przykazania” miały wszak obowiązywać współczesnych jej pisarzy) zdefiniowała $\mathrm{w}$ tym jednym krótkim zdaniu dominujący kierunek, jaki w drugiej dekadzie XXI wieku obierze norweska literatura.

Cezurą wyznaczającą zwrot ku „pisaniu własnego życia”, czyli ku autotematyzmowi/autobiografizmowi/autofikcji w norweskiej literaturze, jest publikacja pierwszego tomu Mojej walki Karla Ovego Knausgårda (2009). Oddziaływanie na norweskie życie literackie i kulturowe ukazującego się w latach 2009-2011 sześciotomowego cyklu ${ }^{3}$ porównać można do oddziaływania właściwego dla trzęsienia ziemi. Krótko po ukazaniu się pierwszego tomu Mojej walki w styczniu 2010 roku związany z Uniwersytetem w Oslo literaturoznawca Arne Melberg opublikował w dzienniku Aftenposten artykuł o znaczącym tytule Brak nam słów, opatrzony dodatkowo podtytułem Akademicka krytyka literacka nie wie, co myśleć ani o Karlu Ovem Knausgårdzie, ani o wielu innych zjawiskach wspótczesnej literatury ${ }^{4}$ (Melberg 2010). Ten dramatyczny nieco w swoim wydźwięku artykuł stanowi bardzo adekwatne podsumowanie problemu, w obliczu którego stanęło norweskie literaturoznawstwo oraz krytyka literacka u progu kolejnej dekady: ponieważ stosowane przez Knausgårda zabiegi literackie z pogranicza autobiografizmu, biografizmu, eseistyki i powieściopisarstwa nie mieściły się w kanonach tego, co i jak w Norwegii wcześniej pisano, nie było jasności, jakimi narzędziami należy je badać i jak je należy oceniać.

Moja walka „wstrząsnęła” bynajmniej nie tylko środowiskiem akademickim. Cykl wzbudził gwałtowne reakcje u bliskich i znajomych autora, którzy rozpoznawszy się na kartach kolejnych jego części, zaczęli nazywać książki Knausgårda „literaturą judaszową" ${ }^{\text {. W }}$ obronie Mojej walki zaczęli stawać na łamach prasy pisarze i dziennikarze (Nilsen 2009). Był to temat, na który w Norwegii „wypadało" mieć zdanie. Historyk literatury Per Thomas Andersen odnotowuje nawet pojawienie się w języku norweskim nowego czasownika å knause (można pokusić się o próbę przetłumaczenia go na język polski jako „knausować”), opisującego sytuację, gdy rozmowa w sytuacji towarzyskiej schodzi nagle i spontanicznie na temat Mojej walki (Andersen 2012).

Wkrótce w ślady Knausgårda poszło wielu innych norweskich autorów, dopuszczających się w swoich powieściach śmiałych prób łączenia elementów auto-

\footnotetext{
${ }^{3}$ W Polsce cykl Moja walka ukazywał się w latach 2014-2018 (Knausgård 2014-2016).

${ }^{4}$ Oryg. „Vi mangler ord. Den akademiske kritikken vet ikke hva den skal mene hverken om Karl Ove Knausgård eller mye annet i dagens litteratur".

${ }^{5}$ Oryg. „Judaslitteratur”.
} 
biografii, biografii i fikcji. Jako przykład podać można powieść Zanim spłonę Gautego Heivolla (2010) ${ }^{6}$, która nie tylko zdobyła prestiżową nagrodę literacką Brageprisen za 2010 rok (rok wcześniej otrzymał ją pierwszy tom Mojej walki), ale stała się też przyczynkiem do szerokiej dyskusji o tym, w jakim stopniu autor powieści ma prawo wykorzystywać w niej historie faktycznie żyjących ludzi oraz jakiego rodzaju moralne implikacje to za sobą pociąga. Powieść Heivolla spotkała się także z miażdżącą krytyką uznanego pisarza Jona Micheleta, który na łamach dziennika Klassekampen napisał między innymi: „Nie powinniśmy tworzyć fikcji o prawdziwych osobach żyjących w czasach nam współczesnych”7 (Lillebø 2010).

Krytyka literacka i literaturoznawstwo w Skandynawii zmuszone były znaleźć słowa niezbędne do badania i oceny tych nowych tendencji literackich, których zdaniem Melberga - brakowało. Eksperymenty, których dopuszczał się Knausgård i pisarze nim zainspirowani, zaczęto wkrótce określać mianem „biografizmu performatywnego" i analizować je jako zjawiska z pogranicza literatury oraz performance’u, w którym autor wykorzystuje siebie samego i inne rzeczywiste osoby do celów estetycznej gry z czytelnikiem (Popa 2017: 163). W 2014 roku ukazała się obszerna praca duńskiego badacza Jona Helta Haardera, w której autor starał się przeanalizować nowe tendencje rządzące skandynawską literaturą w tych właśnie kategoriach. Sam tytuł dzieła: Performativ biografisme: en hovedstrømning $i$ det senmodernes skandinaviske litteratur (Biografizm performatywny: główny nurt w późnonowoczesnej skandynawskiej literaturze) jasno definiuje status opisanych powyżej tendencji nie tylko w Norwegii, lecz w całej Skandynawii.

W nurt ten wpisuje się w pewnym stopniu wydana w 2015 roku powieść De urolige (Niespokojni) Linn Ullmann będąca przedmiotem niniejszego studium. Celem tego tekstu jest analiza formy tej powieści jako tekstu z pogranicza biografii/autobiografii oraz fikcji, a także wskazanie, że De urolige stanowi zjawisko wyjątkowe w literaturze norweskiej, nawet jeśli przyrówna się je do pozycji wzbudzających takie emocje i taką sensację jak cykl Moja walka Knausgårda czy Zanim spłonę Heivolla. W celu znalezienia właściwego teoretycznego klucza do analizy powieści w artykule przedstawione zostaną również najbardziej uznane i adekwatne do przedmiotu badań teorie z zakresu analizy autobiografii oraz autofikcji.

Linn Ullmann przyszła na świat w roku 1966 jako córka sławnych rodziców: Liv Ullmann oraz Ingmara Bergmana. Dorastała w Stanach Zjednoczonych oraz

${ }_{6}^{6}$ Tytuł oryginału: Før jeg brenner ned. Powieść została wydana w Polsce w 2011 r. (Heivoll 2011). 7 Oryg. „Vi bør ikke dikte om virkelige personer i vår egen samtid”. Oburzenie Micheleta wiązało się przede wszystkim z faktem, że Heivoll, oprócz przeżyć i oświadczeń swoich i swoich bliskich, opisał w powieści prawdziwą historię piromana grasującego w 1978 r. w jego rodzinnej wsi Finsland. Tego rodzaju łączenie faktów oraz fikcji bywa także od czasu publikacji $Z$ zimną krwia (1966) Trumana Capote’a określane terminem faction, i do dziś trwają dyskusje na temat konsekwencji natury moralnej, które pociągają za sobą tego typu literackie zabiegi (np. Caudill 2011: rozdział 6). 
norweskim Oslo. Jest autorką sześciu napisanych w języku norweskim powieści, których tematyka oscyluje głównie wokół kwestii rodziny, jej rozpadu oraz napięć w jej obrębie. Na język polski zostały dotychczas przełożone dwie jej książki: debiutancka powieść Zanim zaśniesz (wyd. norweskie 1998, wyd. polskie 2004) ${ }^{8}$ oraz We mgle (wyd. norweskie 2011, wyd. polskie 2016) ${ }^{9}$. De urolige z 2015 roku to jej ostatnia książka, niezwykle entuzjastycznie przyjęta przez krytyków. Ullmann otrzymała za nią nominację do Nagrody Literackiej Rady Nordyckiej (Nordisk Råds Litteraturpris). W chwili powstawania tego tekstu (kwiecień 2018 r.) prawa do tłumaczenia De urolige sprzedane zostały do osiemnastu krajów, w tym Polski.

Jest to jednocześnie jedyna pozycja autorki, w której uczyniła ona głównym tematem siebie samą oraz losy swojej rodziny. Pod względem tematycznym powieść uznać można za „dwutorową", wyróżniają się w niej bowiem dwa główne tematy. Pierwszy to historia dorastania Ullmann, wychowywania się w dwóch domach i złożonych, skomplikowanych relacji budowanych niezależnie od siebie z żyjącymi osobno matką i ojcem, odnajdywania swojej tożsamości w cieniu dwóch wielkich mitów, do rangi których urośli z czasem jej rodzice (zwłaszcza Bergman). Drugą z tematycznych osi De urolige stanowi relacja z ostatnich miesięcy życia ojca Ullmann - obraz choroby, która stopniowo postępuje, powolnego odchodzenia chorego i tego, jak próbuje się z tym pogodzić jego dorosła już córka.

Autorka zdecydowała się zatem opisać nie tylko siebie i swoich sławnych rodziców, lecz także - po części przynajmniej - wtajemniczyć odbiorców powieści w niezwykle intymny rozdział życia swojej rodziny. I choć w pierwszym odruchu można pomyśleć, że szczegółowy opis procesu powolnej śmierci człowieka o takiej międzynarodowej sławie jak Ingmar Bergman może osunąć się w estetykę tabloidowego, „sensacyjnego” reportażu, do niczego takiego w powieści Ullmann nie dochodzi. Przed takim „osunięciem” chroni De urolige wyjątkowa konstrukcja formalna powieści, która zostanie poddana analizie w dalszej części niniejszego tekstu. W pierwszej kolejności warto jednak pochylić się nad adekwatnymi do przedmiotowego tekstu perspektywami teoretycznymi i postarać się odnaleźć wśród nich potencjalny klucz do analizy powieści Ullmann.

\section{Fikcja i „niefikcja” oraz wszystko to, co pomiędzy}

W poszukiwaniu owego teoretycznego klucza warto zacząć od sięgnięcia po klasyczny tekst Philippe’a Lejeune’a Pakt autobiograficzny z 1975 roku $^{10}$. Autor za-

\footnotetext{
8 Tytuł oryginału: Før du sovner.

9 Tytuł oryginału: Det dyrebare.

${ }^{10}$ Tytuł oryginału: Le Pacte autobiographique. Wszystkie cytaty z tego tekstu przytaczane są w niniejszym artykule w przekładzie Aleksandra Wita Labudy.
} 
kłada, iż każde czytanie każdego tekstu wymaga zawarcia swoistego „paktu” pomiędzy autorem a czytelnikiem, to jest sporządzonej na określonych warunkach umowy dotyczącej tego, w jaki sposób tekst będzie rozumiany i odczytywany. Lejeune wprowadza rozróżnienie na „pakt autobiograficzny” oraz „pakt powieściowy”. Pierwsza z wymienionych „umów” zawierana jest w przypadku autobiografii, druga zaś - gdy dzieło literackie ma charakter fikcyjny. O autobiografii możemy zatem mówić w sytuacji, gdy przedstawiony czytelnikowi tekst to „retrospektywna opowieść prozą, gdzie rzeczywista osoba przedstawia swoje losy w ich jednostkowym aspekcie i ze szczególnym uwzględnieniem historii osobowości” (Lejeune 1975: 31). Do zawarcia paktu autobiograficznego będzie zatem dochodziło w sytuacji, gdy tekst cechuje „tożsamość autora, narratora i głównego bohatera” (Ibid.: 32), zaś pakt powieściowy występował będzie w sytuacjach, w których ma miejsce ,jawna praktyka nietożsamości (autor i bohater nie mają tego samego nazwiska) oraz poświadczenie fikcyjności (np. przez podtytuł: powieść [...])” (Ibid.: 39). Tego rodzaju rozgraniczenie porządkuje do pewnego stopnia kategorie fikcyjności i „niefikcyjności”, ma jednak jedynie ograniczone zastosowanie w analizie współczesnej (bądź, jeśli użyć określenia Haardera, „późnonowoczesnej”) norweskiej powieści. Zarówno u Knausgårda, wspomnianego tu Heivolla, jak i Ullmann mamy do czynienia z tożsamością autora, narratora i głównego bohatera (u dwojga ostatnich autorów nie zawsze jednoznaczną i nie we wszystkich partiach tekstu, lecz mimo to niewątpliwą), przy czym ich wspomniane tu dzieła literackie zaopatrzone zostały w podtytuł Powieśćl ${ }^{11}$, będący wedle systematyki Lejeune’a jednoznacznym poświadczeniem paktu powieściowego. Można by wysnuć zatem wniosek, że w „późnonowoczesnej” norweskiej powieści zachodzi coś w rodzaju - jeśli trzymać się lejeune’owskiej nomenklatury - „paktu mieszanego”.

Od tego właśnie założenia rozważania swoje rozpoczyna duński literaturoznawca Poul Behrendt, chcąc wzbogacić wcześniejszy, opisany przez Lejeune’a dychotomiczny podział na pakt autobiograficzny i pakt fikcyjny o kategorię, którą nazywa „podwójnym kontraktem”" ${ }^{2}$. Behrendt poświęcił tej kwestii opublikowaną w roku 2006 książkę Dobbeltkontrakten: en restetisk nydannelse (Podwójny kontrakt: estetyczna nowinka) będącą rozwinięciem rozważań sformułowanych po raz pierwszy w opublikowanym w 1997 roku eseju Med to hoveder. Et essay om 90'ernes astetiske nyskabelse: dobbeltkontrakten ( $\mathrm{Z}$ dwiema głowami. Esej o estetycznej nowince lat 90:: podwójnym kontrakcie). W książce tej Behrendt, wychodząc od dychotomicznego podziału Lejeune’a, zakłada, że do zawarcia obu opisanych przez niego paktów dojść może w ramach tego samego literackiego dzieła. Te równocześnie zawarte pakty nie wykluczają się nawzajem, lecz przyczyniają wspólnie do nadania tekstowi nowego znaczenia. Ustanowienie takiego podwójnego kontraktu

11 Tytuł oryginału: Roman.

12 Oryg. „Dobbeltkontrakten”. 
wymaga zaistnienia dwóch okoliczności. Po pierwsze, oba „pakty” (autobiograficzny i powieściowy) muszą zostać zawarte w odstępie czasowym (jeden wcześniej niż drugi), po drugie zaś, musi dojść do rozpoczęcia gry z czytelnikiem, mającej na celu „Zwiedzenie” go - i gra ta musi zostać zdemaskowana (w momencie takiej demaskacji dochodzi do złamania pierwszego i jednocześnie zawarcia drugiego paktu). Behrendt pisze:

W chwili, gdy tego rodzaju 'sekretne noty' [czyli elementy demaskujące grę przyp. K.D.] zostają ujawnione i wskazane jako integralna część założenia dzieła, objawia się podwójny kontrakt w całej swej istocie: $\mathrm{w}$ formie 'przesunięcia czasowego' w ustanowieniu dwóch wzajemnie wykluczających się określonych kontraktem relacji (2006: 20) ${ }^{13}$.

Koncepcja ta zakłada zatem, że czytelnik do pewnego momentu będzie uznawał, że autor dzieła zawarł z nim pakt autobiograficzny, by po jakimś czasie przekonać się jednak, że był dotychczas oszukiwany, a obowiązującą umową jest pakt powieściowy (albo, rzecz jasna, odwrotnie).

Behrendowska teoria podwójnego kontraktu wprowadza zatem istotną nową kategorię, dopuszczając istnienie dwóch paktów w obrębie tego samego dzieła, jednak także ona pozostaje niewystarczająca do analizy późnonowoczesnych tekstów literatury norweskiej. W żadnej z opisywanych w niniejszym artykule powieści nie dochodzi bowiem do przesunięcia czasowego w zawieraniu dwóch typów paktów, nie można mówić również o „zwodzeniu” czytelnika. Okazuje się zatem, że również takie spojrzenie na kwestię fikcji i „niefikcji” w literaturze jest na potrzeby niniejszej analizy niewystarczające.

Na ratunek w tej sytuacji przyjść może kategoria autofikcji. Termin ten został użyty po raz pierwszy przez francuskiego pisarza Serge’a Doubrovsky’ego (żyjącego w latach 1928-2017) w jego powieści Fils z 1977 roku. W nocie autora wydrukowanej na czwartej stronie okładki książki przeczytać możemy, iż tematem dzieła będzie „fikcja wydarzeń i faktów ściśle rzeczywistych; jeśli się chce, autofikcja, zawierzenie języka przygody - przygodzie języka..."14. Taka definicja zdaje się lepiej niż przedstawione dotychczas koncepcje przystawać do późnonowoczesnej powieści norweskiej. W De urolige Ullmann mamy przecież do czynienia ze ściśle rzeczywistymi, empirycznie możliwymi do udowodnienia faktami (np. narodziny Ullmann, jej wyjazd do USA z matką, małżeństwo i narodziny dzieci, śmierć ojca itd.), przy czym cała opowieść zostaje jednocześnie ujęta w „fikcyjny cudzysłów", co sygnalizuje już chociażby podtytuł Powieść. W wywiadzie udzielonym w roku 2005 Annie Turczyn Serge Doubrovsky, opowiadając o Fils, mówi między

13 Oryg. „I det øjeblik, hvor den slags ‘hemmelige noter' fremkaldes og udnævnes til en integreret del af værkets anlæg, opstår debbeltkontrakten i sin grundlæggende skikkelse - i form af en tidsforskydning i fastlæggelsen af to indbyrdes uforenelige aftaleforhold".

${ }_{14}$ Przekład za: Turczyn 2005: 201. 
innymi: „To sposób powtórzenia mojej historii z elementami ściśle prawdziwymi i jednocześnie całkowicie fikcyjnymi, w stopniu, w jakim ustawiam je razem" (Turczyn 2005: 2009). Sugeruje to zatem zbudowanie powieści poprzez konstrukcję „szkieletu” złożonego z wydarzeń jak najbardziej rzeczywistych i następnie „wypełnienie" go elementami fikcyjnymi, na przykład szczegółowymi opisami tła poszczególnych wydarzeń, rozmów toczonych wokół nich przez ich uczestników itd., czyli elementami wydarzeń rzeczywistych, których autor nie jest w stanie odtworzyć z pamięci (np. z uwagi na upływ czasu), bądź świadomie dodanymi fikcyjnymi segmentami mającymi na przykład wzbogacić opowieść czy podkreślić jakiś jej aspekt.

Współcześni badacze (np. Pierre-Alexandre Sicart czy Karen Ferreira-Meyers), dokonując syntezy przedstawionych powyżej sposobów patrzenia na fikcję i „niefikcję, proponują wprowadzenie kategorii „paktu autofikcyjnego” jako czegoś w rodzaju ich uzupełnienia. Pakt taki miałby dotyczyć „intymnej opowieści, której autora, narratora i głównego bohatera łączy ta sama nominalna tożsamość i której tekst i/lub peryteksty wskazują, że jest ona fikcją"15 (Sicart 2005, cyt. za: Ferreira-Meyers 2005: 210). Ze wszystkich dotychczas przedstawionych koncepcji ta wygląda na najbardziej adekwatną do stanowiącej przedmiot analizy w niniejszym tekście powieści Ullmann. Mamy bowiem ponad wszelką wątpliwość do czynienia z opowieścią: a) intymną, b) w której możemy mówić o tożsamości autora, narratora oraz głównego bohatera, a także c) której perytekst (rozumiany jako elementy usytuowane w obrębie dzieła, do których zalicza się nazwisko autora, tytuł, datowanie, wstępy, dedykacje i motta) wskazuje, że jest ona fikcją.

Późnonowoczesną powieść norweską można rzecz jasna analizować, obierając za punkt wyjścia wszystkie przedstawione powyżej koncepcje bądź też je ze sobą łącząc (rumuńska badaczka Ştefana Popa proponuje na przykład takie teoretycznie przekrojowe spojrzenie na cykl Moja walka, włączając dodatkowo do rozważań elementy teorii biografizmu performatywnego). Na potrzeby niniejszego studium decyduję się jednak spojrzeć na powieść De urolige w świetle takich pojęć jak autofikcja oraz pakt autofikcyjny. Postaram się jednocześnie przedstawić, że powieść Ullmann jako forma pod wieloma względami hybrydowa wymyka się (przynajmniej w swoich fragmentach) wszystkim opisanym powyżej kategoryzacjom.

\section{De urolige jako forma hybrydowa, czyli jak stawić czoła mitowi}

Współistnienie w obrębie powieści fikcji oraz „niefikcji” zostaje zasygnalizowane czytelnikowi, zanim ten jeszcze otworzy książkę. O „kontraktowej” dwoistości

15 Oryg. , an intimate narrative whose author, narrator and protagonist share the same nominal identity and whose text and/or peritext indicate it is a fiction". 
dzieła świadczą jednoznacznie już peryteksty umieszczone na froncie okładki. Pod nazwiskiem autorki oraz tytułem umieszczony zostaje (czcionką o tej samej wielkości, ale innym kolorze) podtytuł Powieść, który sugeruje, że De urolige jest tekstem fikcyjnym. Poniżej (mniejszą czcionką) wydrukowano nazwę wydawnictwa (Forlaget Oktober). Grafika i typografia okładki jest dość surowa i oszczędna - oprócz czterech linii tekstu na szarym tle (na samym dole frontu okładki) wydrukowane zostało jedynie niewielkie, kolorowe zdjęcie (sądząc po jakości - wykonane techniką analogową, a następnie zeskanowane), przedstawiające siedzące na ławce dwie osoby: dziewczynkę w żółtej czapce i dojrzałego mężczyznę ubranego w kamizelkę oraz kraciastą koszulę. Mimo że na stronie redakcyjnej książki nie podano (jak to jest w zwyczaju) opisu tego zdjęcia ani nazwiska fotografa (znaleźć możemy tam jedynie informację, że projekt składu i okładki wykonali Egil Haraldsen i Ellen Lindeberg z firmy EXIL DESIGN) ${ }^{16}$, bez większych wątpliwości czytelnik rozpozna w mężczyźnie Ingmara Bergmana. Można również przypuszczać, że siedząca obok niego dziewczynka to sama Linn Ullmann. Po pobieżnym spojrzeniu na front okładki De urolige czytelnik nabiera przekonania, że tekst dotyczyć będzie żyjących faktycznie osób (co sugeruje biografię/autobiografię), lecz jednocześnie będzie powieścią (co sugeruje fikcję).

Zasugerowane - już przed rozpoczęciem lektury - przeniesienie wydarzeń rzeczywistych w sferę fikcji przyczynia się w powieści Ullmann przede wszystkim do zbudowania dystansu do opisywanych osób i wydarzeń. Dystans ten unaocznia się szczególnie wyraźnie w sposobie przedstawienia trojga „bohaterów” książki, to jest samej autorki i jej rodziców - Liv Ullmann oraz Ingmara Bergmana (przy czym pokusić można się o refleksję, że to właśnie on, nie zaś sama autorka jest „głównym bohaterem" De urolige).

Żadna $\mathrm{z}$ wymienionych trzech osób nie jest identyfikowana na kartach powieści za pomocą swojego imienia i nazwiska. Nazwiska „Ullmann” i „Bergman” pojawiają się co prawda w perytekstach (np. w wymienionych na końcu książki źródłach przytaczanych w tekście cytatów), jednak w samej powieści nie występują, poza dwoma wyjątkami, to jest w następujących fragmentach: „Przechodzimy spacerem do Kościoła Jadwigi Eleonory na Östermalmstorg, gdzie twój dziadek, Erik Bergman, był przez trzydzieści lat pastorem"17 (widzimy zatem, że za pomocą tego nazwiska nie jest identyfikowany ojciec autorki, ale jej dziadek), oraz: „Powiedział: Nie do wiary, czyż to nie pani Ullmann we własnej osobie znów nas odwiedza? Wi-

\footnotetext{
${ }^{16}$ Analiza przedstawiona w niniejszym tekście wykonana została w oparciu o wydanie elektroniczne (e-book) książki z 2015 r. W związku z tym przy odwołaniach do poszczególnych fragmentów dzieła/cytatów nie podaje się numerów stron.

17 Oryg. „Vi spaserer til Hedvig Eleonora kirke på Östermalmstorg der din farfar Erik Bergman var prest i tretti år".
} 
tamy z powrotem w Nowym Jorku!”18 (w tym przypadku „panią Ullmann” nie jest Liv, tylko babka autorki, wypowiadająca cytowaną kwestię). Rodzice Ullmann nie są określani w tekście powieści inaczej niż „ojciec” lub „tata” i „matka” lub „mama"19, pozostając przy tym jednoznacznie rozpoznawalnymi jako Liv Ullmann i Ingmar Bergman. Ten prosty zabieg umożliwia częściowe przynajmniej „przeniesienie" rzeczywistych postaci do świata fikcji i ich odmitologizowanie, pisanie o nich jako o rodzicach, nie zaś gwiazdach światowego formatu.

Podobny, lecz nie do końca identyczny zabieg, autorka stosuje wobec samej siebie. Typowa dla autofikcji narracja pierwszoosobowa (w której postać autorki określana jest zaimkiem ,ja") przeplata się w De urolige z narracją trzecioosobową, w której postać Linn Ullmann występuje jako „ona” lub „dziewczynka”" bry przykład na to, jak zabieg ten jest realizowany w praktyce, stanowi pierwsze w powieści przejście pomiędzy dwoma typami narracji, które pojawia się już na początku pierwszej części powieści. De urolige otwiera narracja pierwszoosobowa. Jednak w momencie, gdy Ullmann opisuje swoje przyjście na świat (jej matka pozostawała wtedy formalnie w związku małżeńskim ze swoim pierwszym mężem), dochodzi do istotnej zmiany:

Byłam w związku z tym, zgodnie z prawem norweskim, „jego” dzieckiem. Ja - 2,8 kilo, 50 centymetrów długości, urodzona we wtorek - byłam lekarską córką i przez wiele miesięcy nosiłam - a raczej ona nosiła - nazwisko Lund. Na fotografiach ma ona okrągłe, pucołowate policzki. Nie wiem o niej znów tak wiele ${ }^{21}$.

Sekwencja ta jasno daje czytelnikowi do zrozumienia, że postać określana zaimkiem „ja” jest tożsama z postacią nazywaną „ona/dziewczynka”, a ta z kolei tożsama jest $\mathrm{z}$ autorką powieści (o czym świadczą chociażby szczegółowe informacje dotyczące okoliczności jej przyjścia na świat).

Narracja trzecioosobowa w De urolige występuje głównie w sekwencjach powieści opisujących dzieciństwo i dorastanie Ullmann, a więc okresy, w których - z uwagi na upływ czasu oraz fakt, że Ullmann nie ma możliwości pamiętania swojego wczesnego dzieciństwa - „szkielet” zbudowany z wydarzeń rzeczywistych musiał najprawdopodobniej zostać $\mathrm{w}$ większym stopniu uzupełniony elementami fikcji.

Opisane powyżej zastosowane w De urolige zabiegi pozwalają na zidentyfikowanie powieści Ullmann jako tekstu $\mathrm{z}$ kategorii autofikcji. Opowieść o dorastaniu

\footnotetext{
${ }^{18}$ Oryg. "- Han sa: Neimen, er det ikke selveste fru Ullmann som er på besøk igjen? Velkommen tilbake til New York!".

19 Oryg. „Far/pappa”, „Mor/mamma”.

${ }^{20}$ Oryg. „Hun/jenta”.

${ }^{21}$ Oryg. „Dermed var jeg ifølge norsk lov hans datter. Jeg - 2,8 kilo, 50 centimeter lang og født på en tirsdag - var legedatter, og i flere måneder het jeg - eller hun - Lund til etternavn. På fotografier har hun runde bollekinn. Jeg vet ikke så mye om henne".
} 
z „ojcem/tatą” i „matką/mamą”, snuta naprzemiennie przez narratora pierwszoi trzecioosobowego stanowi jednak tylko jedną z osi powieści. Już w drugiej (z sześciu) części książki, zatytułowanej Taśmy ${ }^{22}$, następuje „przeskok” bądź też „przeniesienie ciężaru" na drugą z osi - tak tematycznych, jak i formalnych. Wstępem do tej sekwencji jest wyznanie autorki (identyfikującej się w tym miejscu jednoznacznie jako „ja”). Ullmann pisze, że ma niewidoczne dla nikogo poza nią samą skrzywienie kręgosłupa wynikające $\mathrm{z}$ faktu, że nosi na jednym ramieniu torbę, do której wszystko pakuje, a niczego z niej nie wyrzuca. Wymienia następnie wszystkie drobiazgi, które w torbie tej można znaleźć. Na koniec tej wyliczanki dodaje:

Przez wiele lat nosiłam ze sobą w torbie mojego ojca, a raczej to, co mi po nim zostało. Umarł latem 2007 roku, i przez wiele lat leżał tam, przewalając się w tę i z powrotem $\mathrm{z}$ wszystkimi tymi innymi rzeczami.

To, co mi po nim zostało, to sześć nagrań z ostatniej wiosny jego życia. Jego głos. I cisza. I mój głos. I wszystkie te dźwięki wyłapane przez mikrofon, których nie umiem zidentyfikować, a które od biedy nazwać można hałasem. Nagrania zostały zrobione niewielkim szarym dyktafonem wielkości grubszego palca. Wiedziałam, że muszę się jakoś z nimi uporać - to jest z nagraniami. Musiałam je przesłuchać ${ }^{23}$.

Autorka ujawnia zatem, że jest w posiadaniu konkretnych źródeł - taśm, których transkrypcje czytelnik może znaleźć na dalszych kartach powieści, wplecione pomiędzy pierwszo- i trzecioosobową narrację. Autofikcja zostaje dzięki temu wzbogacona o zupełnie nowy i różny - tak pod względem treści, jak i formy - tekst, relację czy wywiad. Mamy zatem do czynienia $\mathrm{z}$ dwoistym procesem powstawania dzieła literackiego, w którym tworzenie (autofikcji) i odtwarzanie (dokonywanie transkrypcji nagranych rozmów) dopełniają się nawzajem w dialektycznym procesie twórczym. Marcin Kafar, wchodząc w swoim erudycyjnym artykule z 2016 roku w dialog z duńskim badaczem Rasmusem R. Simonsenem (2009), pochyla się nad problemem „symetryczności nadawania znaczeń tekstowi, który swą semantyczną (zawsze doraźną) skończoność zyskuje w dopełniających się nawzajem aktach 'pisania' i 'czytania'" (Kafar 2016: 159). Idąc za tą myślą, można postrzegać tekst De urolige jako zbudowany na symetrycznych procesach „pisania” i „słuchania/odsłuchiwania”, to jest wspominanych tu już dwóch osiach powieści.

${ }^{22}$ Oryg. „Spoler”.

${ }^{23}$ Oryg. „I mange år bar jeg faren min, eller det jeg hadde igjen av ham, med meg i veska. Han døde sommeren 2007, og i flere år lå han og ristet frem og tilbake sammen med alle de andre tingene.

Det jeg hadde igjen av ham, var seks lydbåndopptak fra den siste våren han levde. Stemmen hans. Og stillheten. Og stemmen min. Og alle lydene jeg ikke helt vet hva er, som mikrofonen fanget opp, og som upresist kan kalles støy. Opptakene ble gjort med en liten grå båndopptager på størrelse med en tykk finger. Jeg visste at jeg måtte håndtere dem på en eller annen måte opptakene, altså. Jeg måtte høre igjennom dem". 
De urolige objawia się w swoich dalszych częściach czytelnikowi jako „książka o książce, która nigdy nie powstała". Ullmann wyznaje, że przez kilka lat planowała wraz ze swoim ojcem książkę napisaną na podstawie ich rozmów i relacji. Projekt ten nie wyszedł nigdy jednak $\mathrm{z}$ fazy drobiazgowych planów, zupełnie jakby oboje bali się przystąpić do jego realizacji: „Lato 2006 roku. Nadal planujemy książkę i wszystko, co nas czeka. Książka powstanie w wielu fazach. Będzie się rozmawiać, transkrybować, redagować, składać. Wielka praca”24. Wszystko - relacjonuje Ullmann - zmieniło się na wiosnę 2007 roku, gdy u jej ojca zdiagnozowano przemijający atak niedokrwienny, postępujące schorzenie neurologiczne niszczące pamięć i sprawiające, iż pacjent ma kłopoty z odróżnieniem rzeczywistości od nierzeczywistości. Planowany „projekt” zmienia więc szybko charakter - w zbieraniu relacji z ojcem nie chodzi już o pracę nad książką, ale o próbę zachowania pamięci o człowieku, który stopniowo odchodzi. „Czy mogę opłakiwać ludzi, którzy nadal żyją?”, stawia pytanie Ullmann ${ }^{25}$. Sześć nagrań, które nosiła w torbie, wykonano w maju 2007 roku, na niecałe trzy miesiące przed śmiercią Ingmara Bergmana (30 lipca 2007 r.).

Duży czasowy rozdźwięk pomiędzy wykonaniem nagrań a wydaniem De urolige (osiem lat) Ullmann tłumaczy kwestiami natury organizacyjnej i technicznejzawirowaniami w życiu osobistym, przeprowadzkami, a także tym, że przez długi czas wydawało jej się, iż nagranego materiału zwyczajnie nie da się odsłuchać. Zgodnie z tym, co pisze, próbowała zrobić to krótko po śmierci ojca, jednak jakość dźwięku była tak niska, że nie dało się rozróżnić poszczególnych słów. $Z$ torby dyktafon trafił do szuflady, następnie na strych - gdzie Ullmann natknęła się na niego przypadkiem po siedmiu latach od śmierci ojca. Postanowiła podjąć kolejną próbę odsłuchania nagrań i zadzwoniła do swojego dorosłego syna, prosząc go o wsparcie techniczne - dwudziestolatek udzielił jej prostej porady - powinna do dyktafonu podłączyć słuchawki. Dopiero wtedy Ullmann odkryła, że dźwięk został w rzeczywistości nagrany bardzo precyzyjnie: „Sześć nagrań. Gdyby mój ojciec żył, zapytałabym go o pauzy. Ciszę. Odstępy. Jak je oddać? Jak on by to zrobił?”26. Odnieść można wrażenie, że wyjaśnienia dotyczące przeprowadzek, banalnych kłopotów technicznych, problemów małżeńskich Ullmann itd. to tak naprawdę tylko wymówki, mało wiarygodne próby usprawiedliwienia tego, dlaczego nagrania musiały „odczekać” aż siedem lat. Można pokusić się o hipotezę, że nagrane na dyktafon słowa musiały „dojrzeć”, tak jak dojrzeć do ich odsłuchania musiała sama autorka, że tych siedem lat było koniecznych do powstania niezbędnego -

${ }^{24}$ Oryg. „Sommeren 2006. Vi fortsetter å planlegge boka og alt som ligger foran oss. Boka skal bli til i mange faser. Det skal samtales, transkriberes, redigeres, sammenstilles. Et stort arbeid”.

${ }^{25}$ Oryg. „Kan jeg sørge over mennesker som fortsatt lever?”

${ }^{26}$ Oryg. ",Seks opptak. Hvis faren min hadde vært i live, hadde jeg spurt ham om pausene. Stillheten. Mellomrommene. Hvordan gjengi dem? Hvordan ville han ha gjort det?" 
czasowego i emocjonalnego - dystansu pozwalającego przenieść je na karty powieści, tego samego dystansu, który wywołany zostaje poprzez pozbawienie w De urolige Ingmara Bergmana nazwiska i przeistoczenie go w bohatera określanego jako „ojciec/tata”.

Wyjściowy materiał stanowiło zatem sześć nagrań, z których każde, o czym informuje Ullmann, trwało około dwóch godzin. Nagrania te zostały przez autorkę poddane transkrypcji i podzielone na łącznie 19 różnej długości fragmentów, które wplecione zostały w narrację powieści w częściach II, IV, V oraz VI. Nie zostaje przy tym określone, z którego nagrania pochodzi dany fragment transkrypcji, ani też czy transkrypcji poddane zostały wszystkie wykonane przez Ullmann nagrania, w całości lub fragmentach.

Interesująca jest forma, w jakiej dokonano transkrypcji nagrań - wplecione w narrację książki fragmenty rozmowy ojca z córką przywodzą na myśl tekst dramatu (lub filmowego scenariusza) i zapisane zostały jako „kwestie” wypowiadane przez dwie osoby - określone na potrzeby tych fragmentów powieści jako „ON” $\mathrm{i}$ „ONA”27. Nie są to więc rozmowy prowadzone przez „Dziewczynkę” z jej „Ojcem/ Tatą", Linn Ullmann nie ujawnia się też w transkrypcjach czytelnikowi jako "Ja”. Zabieg ten - po raz kolejny - przenosi rozmowy utrwalonych na nagraniach osób - a także same te osoby - w sferę fikcji i umowności. Poza samymi „kwestiami” wymienianymi przez NIĄ i NIEGO w transkrypcjach występują elementy, które można określić jako didaskalia, zapisane kursywą komentarze dotyczące przerw w rozmowie (np. „Długa cisza”, „Pauza” ${ }^{28}$ ), jak i sposobów wypowiadania kwestii przez „osoby dramatu” (np. „ON chrząka”, „ON się waha” ${ }^{29}$ ). Przerwy, pauzy i chwile wahania zdarzają się w poddanych transkrypcji rozmowach nader często, co spowodowane jest kondycją umysłową, w jakiej znajduje się ON: mający kłopoty z pamięcią, nie do końca odróżniający to, co rzeczywiste, od tego, co nieprawdziwe, zdaje się egzystować na granicy snu i jawy. Dlatego też nie zawsze odpowiada na pytania, które zadaje mu ONA, lub odpowiada na nie nielogicznie, sam zadaje pytania, które usłyszał przed chwilą, powtarza słowa, które wypowiada ONA. Z tego powodu rozmowy ulegają dekonstrukcji, rozpadają się na urywane, nie zawsze sensownie ze sobą powiązane kwestie. W recenzji De urolige opublikowanej w dzienniku Dagbladet 21 listopada 2015 roku (powieść otrzymała najwyższą z możliwych ocenę, „sześć oczek” na kostce do gry) krytyk literacki Marius Wulfsberg pisze o tych fragmentach: „Są one tragikomiczne niczym sztuka teatralna Becketta, wypowiadane w nich kwestie ranią i bawią jednocześnie"30

${ }^{27}$ Org. „ON” $\mathrm{i}$ „ONA”.

${ }^{28}$ Org. „Stille lenge”. „Pause”.

${ }^{29}$ Org. „Han kremter”, „HAN (nøler)”.

${ }^{30}$ Org. „De er tragikomiske som et teaterstykke av Beckett, replikkene såre og morsomme på en gang". 
(Wulfsberg 2015: 50). Porównanie do Becketta zasadne jest tym bardziej, że w De urolige pojawiają się kilkukrotne odniesienia do jego twórczości, a także dwa bezpośrednie cytaty z jego listów. Tragikomiczny efekt, o którym pisze Wulfsberg, został osiągnięty za pomocą zabiegów formalnych pozwalających przenieść rozmowy Ullmann z Bergmanem do sfery fikcji i niedookreślenia - podobnie jak sama osoba określona mianem ON rozmowy egzystują na pograniczu rzeczywistości i „nierzeczywistości”, snu i jawy.

Podsumowując wszystkie opisane powyżej zabiegi wykorzystane w De urolige, dojść można do wniosku, że mają one na celu przeniesienie obu opowieści (historii życia „dziewczynki” oraz historii umierania „ojca/taty/JEGO”) z poziomu intymnego wyznania o osobistym doświadczeniu do sfery pewnej ogólności i uniwersalności (uczynienie z nich historii „o dorastaniu” i „o umieraniu”), przełożenie niezwykle osobistej rodzinnej historii na język literatury.

Analizując De urolige na tle innych norweskich „późnonowoczesnych” powieści grających konwencją autobiografii, biografii, autofikcji, faction, biografizmu performatywnego itd., warto zwrócić uwagę na charakterystyczną cechą, którą książka Ullmann się wyróżnia. Jest to wielopoziomowa hybrydowość tekstu, objawiająca się tak w jego tematyce (stylizowana autofikcyjna opowieść stanowi w rzeczywistości przyczynek do stworzenia poruszającej, intymnej historii o starości, chorobie, śmierci, o stopniowym żegnaniu się z odchodzącym bliskim człowiekiem i radzeniu sobie $\mathrm{z}$ tą "stratą na raty”), jak i formie (przeplatanie się różnych form narracji, a nawet rodzajów literackich: epiki i dramatu). W De urolige zatarta zostaje granica pomiędzy autofikcją a stylizowaną relacją/reportażem, tekstem opartym na konkretnych, empirycznie weryfikowalnych źródłach. I choć powiedzieć można, że ze źródeł tego rodzaju w swoich autofikcyjnych czy performatywnych relacjach korzystali również inni norwescy autorzy (np. Gaute Heivoll, wplatający w narrację Zanim spłonę fragmenty dzienników swojej babki), to jednak należy przyznać, że Ullmann wykorzystała je w sposób unikalny, nadając im nową literacką formę, brzmienie i jakość.

Co ciekawe, pomimo dużej szczegółowości i wysokiego stopnia intymności opowiadanej w De urolige historii powieść nie spotkała się z protestami środowiska literackiego, krytyków ani osób w niej opisanych (jak miało to miejsce w przypadkach np. Mojej walki i Zanim spłonę). Przyczyn takiego stanu rzeczy doszukiwać się można w dwóch faktach: po pierwsze, Ullmann opowiada historię, która „należy” do niej - jest to opowieść o jej życiu i jej radzeniu sobie ze śmiercią ojca, ma zatem do niej „prawo” (w odróżnieniu od na przykład Heivolla, któremu zarzucano, że nie ma "prawa” do historii opisanego w Zanim spłonę piromana); po drugie zaś, opisana w niniejszym tekście gra formą i konwencją powieści spełnia funkcję „bezpiecznika” w powieści, nie pozwalając osunąć się jej w sensacyjną, tabloidową estetykę. 
„Patrzeć, pamiętać, pojmować. Wszystko zależy od punktu widzenia”" ${ }^{31}$ - tak rozpoczyna Linn Ullmann swoją powieść. De urolige to nie tylko historia o dorastaniu i śmierci, ale też fascynujący obraz, jak historia taka może być pamiętana, przypominana, tworzona i odtwarzana, poruszające świadectwo pamięci i jej literackiego zapisu.

Bibliografia

Literatura podmiotu

Ullmann, L. (2015). De urolige. Oslo: Forlaget Oktober, e-book.

Literatura przedmiotu

Andersen, P.T. (2012). Norsk samtidslitteratur. Om norsk litteratur de siste 10-20 år. Niepublikowany wykład wygłoszony na Uniwersytecie Gdańskim 12 kwietnia 2012 roku.

Behrendt, P. (1997). Med to hoveder. Et essay om 90'ernes æstetiske nyskabelse: dobbeltkontrakten. Weekendavisen (bøger) 43: 9-10.

Behrendt, P. (2006). Dobbeltkontrakten: en cestetisk nydannelse. København: Gyldendal.

Bjørnstad, K. (2001). Joeger: en rekonstruksjon. Oslo: Aschehoug.

Books from Norway. (niedatowane). Linn Ullmann: Unquiet, http://booksfromnorway.com/ books/90-unquiet (dostęp: 27.03.2018).

Capote, T. (2013 [1966]). Z zimną krwia. Tłum. K.F. Rudolf. Poznań: Rebis.

Caudill, D.S. (2011). Stories About Science in Law: Literary and Historical Images of Acquired Expertise. Burlington: Ashgate Publishing Company.

Doubrovsky, S. (1977). Fils. Paris: Les Éditions Galilée.

Ferreira-Meyers, K. (2005). Autobiography and Autofiction: No Need to Fight for a Place in the Limelight, There is Space Enough for Both of these Concepts. W: K.W. Shands, G.G. Mikrut, D.R. Pattanaik i K. Ferreira-Meyers (red.). Writing the Self. Essays on Autobiography and Autofiction. English Studies 5. Södertörns högskola: Elanders, s. 203-2018.

Haarder, J.H. (2014). Performativ biografisme: en hovedstrømning i det senmodernes skandinaviske litteratur. København: Gyldendal.

Heivoll, G. (2010). Før jeg brenner ned. Oslo: Tiden.

Heivoll, G. (2011). Zanim spłonę. Tłum. M. Gołębiewska-Bijak. Warszawa: Świat Książki.

Kafar, M. (2016). „Prawdziwe zmyślenie” w praktyce badawczej. Między doświadczaniem „bycia w terenie” a doświadczaniem literatury - podróż z Paulem Austerem. W: M. Kafar (red.). Auto/biograficzne aspekty praktyk poznawczych. Łódź: Wydawnictwo Uniwersytetu Łódzkiego, s. 147-172.

Knausgård, K.O. (2009-2011). Min kamp, bok 1-6. Oslo: Forlaget Oktober.

Knausgård, K.O. (2014-2016). Moja walka, księgi 1-6. Tłum. I. Zimnicka. Warszawa: Wydawnictwo Literackie.

Lejeune, P. (1975). Pakt autobiograficzny. Tłum. A.W. Labuda. Teksty: teoria literatury, krytyka, interpretacja 5 (23): 31-49.

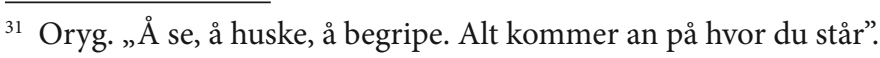


Lillebø, S. (2010). Et speil for virkeligheten. Klassekampen, 3 listopada 2010. http://www.klassekampen.no/58139/article/item/null/et-speil-for-virkeligheten (dostęp: 20.03.2018).

Melberg, A. (2010). Vi mangler ord. Aftenposten, 15 stycznia 2010. https://www.aftenposten.no/ meninger/kronikk/i/mB9jL/Vi-mangler-ord (dostęp: 20.03.2018).

Nilsen, G.J. (2009). Ikke judaslitteratur. Aftenposten, 22 grudnia 2009. https://www.aftenposten. no/meninger/debatt/i/mBlb0/Ikke-judaslitteratur (dostęp: 20.03.2018).

Popa, S.. (2017). „My Struggle” - from Autobography to Performative Biographism. Studia UBB Philologica 62 (3): 155-166.

Sicart, P.-A. (2005). Autobiographie, Roman, Autofiction. Praca doktorska, New York: New York University.

Simonsen, R.R. (2009). Even or(r) odd. The game of narration in Paul Auster's Oracle night. American Studies in Scandinavia 41 (1): 83-107.

Svanholm, L. (2001). Malerne på Skagen. København: Gyldendal.

Turczyn, A. (2005). „Fikcja wydarzeń ściśle rzeczywistych”. Z Sergem Doubrovskim rozmawia Anna Turczyn. Teksty Drugie 5: 201-212.

Ullmann, L. (1998). Før du sovner. Oslo: Forlaget Oktober.

Ullmann, L. (2005). Zanim zaśniesz. Tłum. M. Ciszewska i J. Sypniewska. Gdańsk: Słowo/obraz terytoria.

Ullmann, L. (2011). Det dyrebare. Oslo: Forlaget Oktober.

Ullmann, L. (2016). We Mgle. Tłum. I. Zimnicka. Warszawa: Wydawnictwo W.A.B.

Ullmann, L. (2018). Niespokojni. Tłum. I. Zimnicka. Warszawa: W.A.B.

Wulfsberg, M. (2015). Årets beste selvbiografiske roman. Dagbladet, 21 listopada 2015: 50-51. 